\title{
RELIGIOUS CULTURE AND HEALTH PROMOTION: CARE, PRACTICE, OBJECT
}

Editorial

At the margins of modern medical practice, pushing the very limits of science, and indefatigably rendering the precincts of public discourse, still functional remnants of Christian civilization continue to provide care for the hopeless, perform healing sacraments for the incurable, and curate objects of votive devotion for the suffering and needy. These public services go largely unaccounted for, though they secure an ordered world, structure perception, and serve as ontological anchors. Lost in the vague, scientifically unrarified notions of spirituality that brace a general, undifferentiated worldwide metaphysical experience and disregard immense cultural, functional, geographic and performative distinctness, Catholic sacramental practices aimed at alleviating suffering and promoting healthy lifestyles are receiving only marginal mention in scientific literature ${ }^{(1)}$, despite the fact that they make up daily reality in large parts of contemporary Europe and Latin America.

Writing this editorial from the Northeast of Brazil, where traditional religious practice has sustained generations through the calamities of severe droughts, slavery, extreme poverty, high child mortality, failed political orders, and a harsh global economic reality, it is difficult to underestimate the power of sacramental experience to sustain a cultural identity.

It was defined the concept of care of the sick in the context of the religious experience of the Northeast of Brazil which is historically relevant to health promotion. Until the emergence of national health care in the late nineteenth century, it was largely the order of the Franciscan friars that was charged with promoting healthy lives in the region. The Catholic concept of care that guided their efforts structures three procedural reality principles: the psychological reality of the transference to the person in one's charge (care/caritas), the performative practice of religious sacrament such as the anointment of the sick or ex-voto devotionals, and the physical object representing either the symptom or the instrument of medical or divine intervention.

Pope Benedict's first encyclical (2), "Deus Carita Est", placed the notion and practice of caritas, meaning love, virtue and charity or grace, at the center of social justice and social - health - care. Yet, the public domain where communicative action ${ }^{(3)}$ on behalf of health promotion and equity of care can be undertaken and carried out is the modern technologically engineered mass, which is very different from the traditional religious congregation, and represents a complex system not reducible to governmental bureaucracies and political structures. Our thesis is that public - mass formatted health design can only obtain a measure of its efficiency by gauging medical and juridical interventions with covenantal or votive procedural reality, as well as with the psychological-libidinal authenticity of care deposited in cultural artifacts as objects of relation and communication.

Hannah Arendt ${ }^{(4)}$ was the first philosopher of the twentieth century to call attention to the social reality of the Christian caritas, a bold move given the mass dimensions of the group she was envisioning. She also documented the binary opposition between sexual, carnal love and duty-bound, creaturely love that dominated social thought around the world wars ${ }^{(4)}$. In contrast to Arendt and all mass sociologists, the covenantal female sexuality is also believed to be a vital part of the concept of God's love $e^{(2)}$, indeed its very anchor in material reality, which has important implications for family health promotion, the design of public spaces, the health of the individual oikos and of group economies.

In a recent commentary ${ }^{(5)}$ on an evolutionist exhibit celebrating otherwise vague and imprecise evidence of a purported survival of Neanderthal achievements, was concluded that regrets about the omission of medical knowledge from the show's congratulatory homage to homo sapiens's scientific progress with the invocation of an artist's rendition of 
the precarious place occupied by modern medicine in the larger historical panorama, namely Gustav Klimt's now lost depiction of the ancient goddess Hygieia flanked by the allegorical figures of Sickness and Death. The intuitive artist interpretation not only reinstates the reality to which the medical sciences are called to perform their duties, namely finitude and suffering, but also places the two distinct -- regrettably still irreconcilable - origins of modern medicine side by side: Greco-Roman rationality and scriptural-sacramental culture rooted in the Christian notion of caritas, which organized the procedural space of the modern hospital and the modern orphanage, the two key historical developments that gave birth to contemporary health welfare and health promotion systems.

The traditions of votive practice, especially the sacred rite of delivering an ex-voto as payment for healing and fulfillment of a promise contracted and carried out in the "metaphysical" realm of language and representational media, are not so much prototypical ideas or proto-phenomena of welfare and promotion, but of the linguistic performative act of ontologization supporting the existence, of what was termed Fuersorge $^{(6)}$ (German for welfare, but also care as in Arendt's caritas, and the organization of the future). Promotional activity falls under the paradigm of Fuersorge as main ontological principle structuring the social reality of the welfare system of values and of scientific thought, but Fuersorge was irreducible to political principle and state governance ${ }^{(6)}$. In this oeuvre, it is a much richer term referring to the cultural-poetic birth of the future $^{(6)}$. Likewise, the reality of Catholic language, practice, and artifacts, though it gave birth to the scientific-technological complex of modern industry, medicine, and state-juridical bureaucracies, differs from the rational structures it made possible in that it remains irreducible to mere means to an end. As means to an end, the scientific-technological complex aims at total mastery of the future of the biopolitical ${ }^{1}$ and material domains.

In a reflection on technology $\mathrm{y}^{(7)}$, on the other hand, follows the traces of its existence in the world in a marked departure from the standard conception of it as mere instrumentality, that is, as means to an end, by uncovering the hidden meaning and potentiality in the poetic-cultural linguistic formations that not only reflect its phenomenological horizon, but structure its presence. Though remains religious experience in a blind spot, this analysis still continues nevertheless prescribed and inscribed in a language profoundly altered by the material artifacts of a textual and sacramental religious history in the German context ${ }^{(7)}$.

Excavating the religious-historical genealogy of our contemporary notions of care, its object and practice, and the organizational principles of the public sphere it structures is one side of the task this volume sets for itself. The other side of the question is practical and aims to begin to focus an academic discourse that can support, value, and safeguard traditional religious practices today, not as means to an end, but as cultural structures vital to public space design and health promotion, and as a point of check-and-balance to political structures that tend to monopolize their grip on the public sphere. The goal is to harmonize the two distinct and until now largely antagonistic origins of contemporary scientific thought and health promotion, the rational Greco-Germanic tradition, supported by physics, metaphysics and phenomenology, and the sacramental - originally Hebraic - Catholic tradition, which organizes the ontological anchors of caritas.

This journal, Brazilian Journal in Health Promotion, is looking forward to the development of theoretical paradigms that can support research at the intersection between health promotion and religious practice. We are especially interested in models of collaboration between religious and health institutions aimed at research and design of physical and virtual public spaces marked and structured by notions of health, disease, and individual anatomical representations.

\section{REFERENCES}

1. Holmes S. Beholden: religion, global health, and human rights. Oxford: Oxford University Press; 2015.

2. Papst Benedikt XVI. Enzyklika: Deus Carita Est [accessed on 2015 Mai 13]. Available at: http://w2.vatican.va/ content/benedict-xvi/de/encyclicals/documents/hf_benxvi_enc_20051225_deus-caritas-est.html

3. Habermas J. Theory of communicative action. Boston: Beacon Press; 1985.

4. Arendt H. Love and St. Augustine. Chicago: University of Chicago Press; 1996.

5. Horton R. Offline: medicine's precarious place in the history of humanity. Lancet. 2015;386(9996):840.

6. Heidegger M. Sein und Zeit. $16^{\text {th }}$ ed. Tübinguen: Max Niemeyer; 1986.

7. Heidegger M. The question concerning technology. In: The question concerning technology and other essays. New York: Harper; 1969. p. 3-35.

\section{Mailing address:}

Viola Timm

Universidade de Fortaleza

Mestrado de Saúde Coletiva

Av. Washington Soares, 1321

Bairro: Edson Queiroz

CEP: 60.811-905 - Fortaleza - CE - Brasil

E-mail: timmviola@googlemail.com

\footnotetext{
${ }^{1}$ In the sense of Michel Foucault's use of the term.
} 